\title{
Linking Fisher Perceptions to Social-Ecological Context: Mixed Method Application of the SES Framework in Costa Rica
}

\author{
Stefan Partelow ${ }^{1}$ (D) Anne Jäger ${ }^{1}$ - Achim Schlüter ${ }^{1,2}$
}

Accepted: 12 March 2021 / Published online: 26 March 2021

(C) The Author(s) 2021

\begin{abstract}
There are few studies about how social-ecological context is linked to actor perceptions in environmental governance, although it is evident that resource use behavior, participatory processes, rule compliance, and cooperation are influenced by actors' perceptions. We apply and combine Ostrom's social-ecological systems framework (SESF) and Bennett's (2016) perception framework to identify the contextual variables influencing different perceptions in a case study of small-scale fisheries comanagement in Costa Rica implementing a marine protected area. Analytically, we use network analysis tools to analyze qualitative interview data in a way that links the two frameworks, and content analysis to provide contexutally meaningful descriptions of those network patterns in practice. Our findings suggest Bennett's perceptions framework can be expanded and that the SESF is useful to identify how perceptions relate to more social and ecological variables than prior research suggests. Our findings demonstrate the importance of understanding perceptions and context in environmental governance analyses and practice. We conclude with reflections on local policy challenges.
\end{abstract}

\section{Resumen}

Existen pocos estudios sobre cómo el contexto socioecológico está vinculado a las percepciones de los actores en la gobernanza ambiental. Sin embargo es evidente que el uso de los recursos, los procesos participativos, el cumplimiento de las normas y la cooperación están influenciados por las percepciones de los actores. Aplicamos y combinamos el marco de sistemas socioecológicos (SESF) de Ostrom y el marco de percepción de Bennett (2016) para identificar las variables contextuales que influyen las percepciones de los actores en un estudio de cogestión de pesquerías a pequeña escala en Costa Rica para la implementación de un área marina protegida. Nuestros hallazgos sugieren que el marco de percepciones de Bennett puede ampliarse y que el SESF es útil para identificar cómo las percepciones se relacionan con más variables sociales y ecológicas de lo que sugiere la investigación anterior. Nuestros resultados demuestran la importancia de comprender las percepciones y el contexto en los análisis y la práctica de la gobernanza medioambiental.

Keywords Governance $\cdot$ Small-scale fisheries $\cdot$ Marine protected area (MPA) $\cdot$ Mental models $\cdot$ Psychology $\cdot$ Behavioral economics · Social-ecological systems framework (SESF) · Central America · Costa Rica · Gulf of Nicoya

Palabras claves Gobernanza · Pesquerías a pequeña escala · área marina protegida (AMP), modelos mentales · psicología · economía del comportamiento · marco de sistemas socioecológicos (SESF) · América Central · Costa Rica · Golfo de Nicoya

Stefan Partelow

stefan.partelow@leibniz-zmt.de

1 Leibniz Centre for Tropical Marine Research (ZMT), Bremen, Germany

2 Jacobs University, Bremen, Germany

\section{Introduction}

Psychologists, philosophers, and spiritual leaders have long recognized the importance of how we perceive the world, and its implications for how and why our perceptions can shape our behavior as individuals (Jones et al. 2011) and within groups (Lubell 2002; Matta and Alavalapati 2006; 
Iftekhar and Pannell 2015; Cinner 2018). However, understanding the variables that influence our perceptions and how these then influence individual and group behavior arguably remains decoupled from many frameworks and theories in environmental governance and community co-management (Iftekhar and Pannell 2015; Bennett 2016; Beyerl et al. 2016; Cinner 2018; Partelow et al. 2020).

Psychology defines perceptions as the internal processing of sensory information (Steg et al. 2012; Lindsay and Norman 2013; Beyerl et al. 2016). However, we more loosely see them as a relationship between people and their environment, how these relationships are internalized and influencing understandings of, and decisions made within, the systems they are a part of. We also adopt Bennett's definition: "perceptions refer to the way an individual observes, understands, interprets, and evaluates a referent object, action, experience, individual, policy, or outcome" (2016: 585). Although this study does not focus on a specific theory in environmental psychology, there are many that can be applied to an environmental governance context (Biel and Thøgersen 2007; Steg and Vlek 2009; Grunblatt and Alessa 2017; see also Stern 2000, Saunders et al. 2006, and Beyerl et al. 2016 for summaries).

Recent co-management literature suggests that focusing on human behavior, social norms, and human psychology is critical for understanding how local governance can work better in practice (Vlek and Steg 2007; Kinzig et al. 2013; Iftekhar and Pannell 2015; Gelcich and Keeffe 2016; Nyborg et al. 2016; Reddy et al. 2017; Yoeli et al. 2017; Cinner 2018; Spranz et al. 2018; Wagner 2019). There is increasing recognition that traditionally separate fields such as biodiversity conservation, social organization, and livelihood security are better conceptualized as interdependent social-ecological systems (Ostrom 2009; Colding and Barthel 2019). Numerous social-ecological frameworks attempt to connect and synthesize these efforts to guide future interdisciplinary research (Binder et al. 2013; Pulver et al. 2018) but lack empirical applications on how perceptions influence human behavior and are linked to other system variables and outcomes (Partelow 2018; Wagner 2019).

Qualitative, quantitative, and experimental methods are being used to examine individual perceptions in numerous areas including the context of cooperation (Cárdenas and Ostrom 2004; Matta and Alavalapati 2006), governance legitimacy (Paloniemi and Vainio 2011; Bouma and Ansink 2013), environmental management strategies or policies (Lubell 2003; Pini et al. 2007; Molina-Terrén et al. 2016; Carmenta et al. 2017; Turner et al. 2018), adaptive capacity (Grunblatt and Alessa 2017), social values, preferences, or outcomes (Raymond et al. 2009; Dickman 2010; Nzau et al. 2018; Nelson et al. 2019), and environmental outcomes (Lindell et al. 2014; Delgado-Serrano et al. 2015). This is a salient topic for resource management, as policies often require behavior change of resource users (e.g., compliance with seasonal restrictions, gear use, harvesting reductions), but knowledge about how perceptions influence behavior in relation to those policies and goals is lacking (Wagner 2019).

Here we provide an observational and methodological step towards identifying individuals' perceptions and linking them to the broader social-ecological system variables that encompass their experience of their governance reality. We offer conceptual guidance for further research by linking two frameworks in each area. We hypothesize an iterative relationship between the context of a system (i.e., its unique social and ecological variables) and the actors' perceptions about it. However, we do not yet understand the variation or degree to which social or ecological variables may be influencing resource users' perceptions. We also do not know the extent to which they may or may not be influencing their actions and behaviors. We explore these linkages in a small-scale fishing community in Costa Rica where a co-management approach to govern a marine protected area is being implemented, referred to locally as Marine Areas for Responsible Fishing (AMPR). After our results, we discuss combining our frameworks for further research and the implications for the case study.

\section{Two Conceptual Frameworks}

Bennett's (2016) framework has four categories of perceptions that an individual may have in relation to environmental governance: (1) social outcomes, (2) ecological outcomes, (3) governance/ management legitimacy, and (4) governance/ management acceptability (Table 1), based on a recent review of environmental conservation and management literature. Importantly, it is supported and positioned within the literature on environmental governance and fisheries. Legitimacy and acceptability are related categories but can be difficult to differentiate. Legitimacy can be measured with different indicators including participation, transparency, accountability, flexibility, collaboration, leadership, vision, and communication (ibid.). Acceptability refers to whether governance is aligned with different social, cultural, political, and economic contexts (ibid.) and is accepted as legitimate by them such as indigenous or local communities outside government policy-making circles.

Ostrom's SESF is a multi-tier diagnostic and theoretical framework for collective action (Ostrom 2007, 2009; McGinnis and Ostrom 2014; see also Partelow 2018) composed of eight first-tier variables, each containing a nested set of more than 50 s-tier variables (Table 2). However, the variable that most closely relates to the role of perceptions is 'Knowledge of SES/ Mental models (A7),' which is difficult 
Table 1 A framework presenting the different categories of perceptions and their basis for evaluation from Bennett (2016)

\section{Basis of evaluation}

\begin{tabular}{|c|c|}
\hline Perceptions of social outcomes (PSO) & $\begin{array}{l}\text { Nature and magnitude of social impacts (costs and benefits); equity in distribution of social costs and } \\
\text { benefits }\end{array}$ \\
\hline erceptions of ecological outcomes (PEO) & $\begin{array}{l}\text { Impacts on environmental quality and productivity; impacts on provisioning of ecosystem services and } \\
\text { benefits }\end{array}$ \\
\hline $\begin{array}{l}\text { Perceptions of governance/ management } \\
\text { legitimacy (PL) }\end{array}$ & $\begin{array}{l}\text { Quality of governance processes; appropriateness and inclusiveness of governance structures; legitimacy } \\
\text { policies, rules, and decision makers }\end{array}$ \\
\hline $\begin{array}{l}\text { Perceptions of governance/ management } \\
\text { acceptability (PA) }\end{array}$ & $\begin{array}{l}\text { Presence or absence of management inputs; appropriateness of conservation models; acceptability of } \\
\text { management actions; quality of engagements with conservation managers }\end{array}$ \\
\hline
\end{tabular}

to define because it contains two concepts with multiple potential meanings that are difficult to measure empirically without further conceptual guidance. It broadly incorporates perceptions and is one of the least focused on 'Actor' variables of the SESF (Partelow 2018).

Related Ecosystems (ECO).

ECO1- Climate patterns ECO2- Pollution patterns ECO3Flows into and out of SES.

\section{Small-Scale Fisheries Co-Management on Isla Venado, Costa Rica}

The Gulf of Nicoya is the largest tropical estuary in Central America, located on the Pacific Ocean coast of Costa Rica. The gulf supports thousands of small-scale fishers in rural coastal communities (Lozano and Heinen 2016; Sabau 2017; Carrillo et al. 2019). The Costa Rican Institute for Fisheries

Table 2 The social-ecological systems (SES) framework (McGinnis and Ostrom 2014)

\section{Social, Economic, and Political Settings (S)}

S1- Economic development. S2- Demographic trends. S3- Political stability.

S4- Other governance systems. S5- Markets. S6- Media organizations. S7- Technology.

\section{Resource Systems (RS)}

RS1- Sector (e.g., water, forests, pasture)

RS2- Clarity of system boundaries

RS3- Size of resource system

RS4- Human-constructed facilities

RS5- Productivity of system

RS6- Equilibrium properties

RS7- Predictability of system dynamics

RS8- Storage characteristics

RS9- Location

\section{Resource Units (RU)}

RU1- Resource unit mobility

RU2- Growth or replacement rate

RU3- Interaction among resource units

RU4- Economic value

RU5- Number of units

RU6- Distinctive characteristics

RU7- Spatial and temporal distribution

\section{Interactions (I)}

I1- Harvesting

I2- Information sharing

I3- Deliberation processes

I4- Conflicts

I5- Investment activities

I6- Lobbying activities

I7- Self-organizing activities

I8- Networking activities

19- Monitoring activities

I10- Evaluative activities
Governance Systems (GS)

GS1- Policy area

GS2- Geographic scale of governance

GS3- Population

GS4- Regime type

GS5- Rule-making organizations

GS7- Property-rights systems

GS8- Repertoire of norms and strategies

GS9- Network structure

GS10- Historical continuity

Actors (A)

A1- Number of relevant actors

A2- Socioeconomic attributes

A3- History or past experiences

A4- Location

A5- Leadership/entrepreneurship

A6- Norms (trust-reciprocity)/ social capital

A7- Knowledge of SES/mental models

A8- Importance of resource (dependence)

A9- Technologies available

Outcomes (O)

O1- Social performance measures

O2- Ecological performance measures

O3- Externalities to other SESs 
and Aquaculture (INCOPESCA) responsible for national fisheries governance supports a small-scale fisheries comanagement program to create Responsible Fishing Areas (AMPRs) to align with the United Nations Food and Agriculture Organization (FAO) Voluntary Guidelines for Securing Sustainable Small-Scale Fisheries (Jentoft et al. 2017; Sabau 2017). AMPRs are a form of marine protected area that allows certain types of resource use with explicit goals to support community-based co-management with INCOPESCA by developing community-based rules for fishing (Fargier et al. 2014; Lozano and Heinen 2015; Rivera et al. 2017; Carrillo et al. 2019) to enhance ecological conservation and social welfare by pursuing alternative livelihood opportunities not based on resource extraction (i.e., aquaculture and tourism). Fishing communities willing and able to self-organize a fishing association and develop a management plan can apply for support from INCOPESCA for an AMPR allowing legitimized access and withdrawal rights and participation in some management decisions with the responsible agencies within a spatially defined marine area (Lozano and Heinen 2015, 2016). The process of creating local fishing associations, historical self-organization of the community, and interactions with INCOPESCA involve collective action through the participation, deliberation, and decision-making of fishers and community members about rules and management strategies for the AMPR (Lozano and Heinen 2015; Rivera et al. 2017; Carrillo et al. 2019).

The AMPR on Isla Venado is one of seven AMPRs in the Gulf of Nicoya. The island is in the upper-middle gulf, close to the eastern shore of the inner Nicoya Peninsula (Fig. 1), only $3.5 \mathrm{~km}^{2}$ with 750 people (in 2015) in three artisanal fishing communities (Florida, Jícaro, and Oriente). The AMPR was established in 2015 to conserve vital mangrove habitat for fisheries between the island and the mainland and to develop alternative livelihoods through attracting small-scale tourism to the island and developing aquaculture. The Asociación Local de Pescadores (ASLOPE - Association of Local Fishers) was formed by fishers and community members from Florida, the community located on the western shore of the island closest to the mainland and mangrove habitat and acts as the representative organization from the community that interacts with INCOPESCA for comanagement of the AMPR. The association includes approximately 55 people, mostly fishers, patrons (market middlemen), and community members (mostly nonfisher women and retired fishers) and is tasked with establishing fishing regulations and collective-choice rules (i.e., rules for making the rules and who can participate) to govern the AMPR. INCOPESCA provides legal support and assistance. Monitoring and enforcement rights are given to communities but are also a responsibility at the national level of the Guarda Costa (Coast Guard).
However, responsibilities for nearly all AMPR governance are expected from the communities, empowering local fishing communities to take control of resource management that has historically been controlled by the central government (Carrillo et al. 2019). Small-scale fishers have been historically marginalized in national development processes, and the AMPRs represent a move towards more inclusive approaches. However, they nonetheless face substantial challenges for practical implementation.

We address the following research questions: (1) Which SESF variables relate to fishers' perceptions of AMPRs? (2) Using Bennett's perceptions categories, what fisher perceptions can be linked to AMPR governance and socialecological context? (3) How can quantitative network methods help identify relationships and groupings in our qualitative data between contextual variables and specific perceptions about AMPR governance?

\section{Methods}

\section{Data collection}

We conducted participant observations and qualitative semistructured interviews throughout field work in February and March of 2017. One of our team (AJ) lived in the community continuously during field work, and we all visited the community at various points (SP and AS). We interviewed six key informants (community leaders, ASLOPE, INCOPESCA) and 18 community members without leadership roles, mostly either members of the two local fishing organizations, the Local Fisher Association of Florida, Isla Venado and unaffiliated fishers. Each interview was conducted in Spanish and lasted between $45 \mathrm{~min}$ and two hours. We conducted additional semi-structured interviews $(n=16)$ with key informants (INCOPESA, leaders of other communities, local NGOs, local academics) for a parallel study by Carrillo et al. (2019). This provided data on Gulf issues related to fisheries, the island, and AMPRs.

Interview questions were guided by the variables of the SESF, and generally followed a diagnostic approach (Ostrom 2007; Cox 2011) to identify the key variables characterizing how the fishery functions as a social-ecological system. Semi-structured interviews were structured loosely around the first-tier variables of the SESF, asking how each interviewee perceives how the system functions (i.e., what variables are important) and how they may be interacting. This provided a basis for understanding how each actor perceives system functionality. Interview questions also addressed governance challenges facing the fishery to assess how those challenges are perceived and context under which those perceptions are formed. Interviews typically began with 

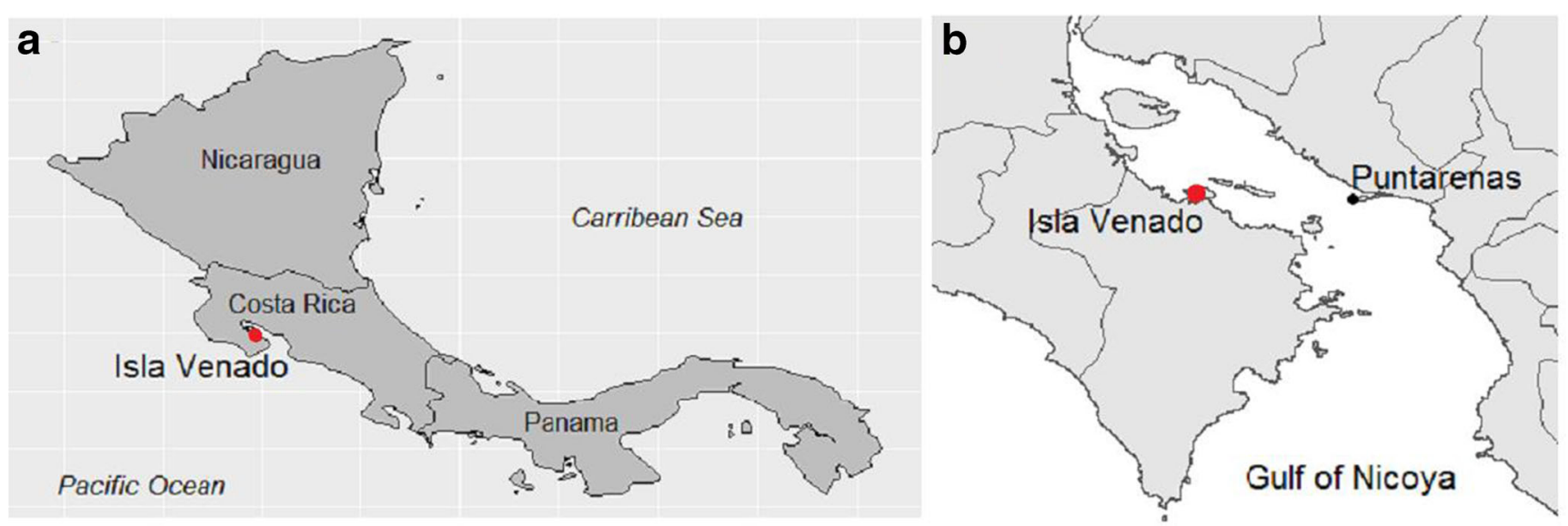

C
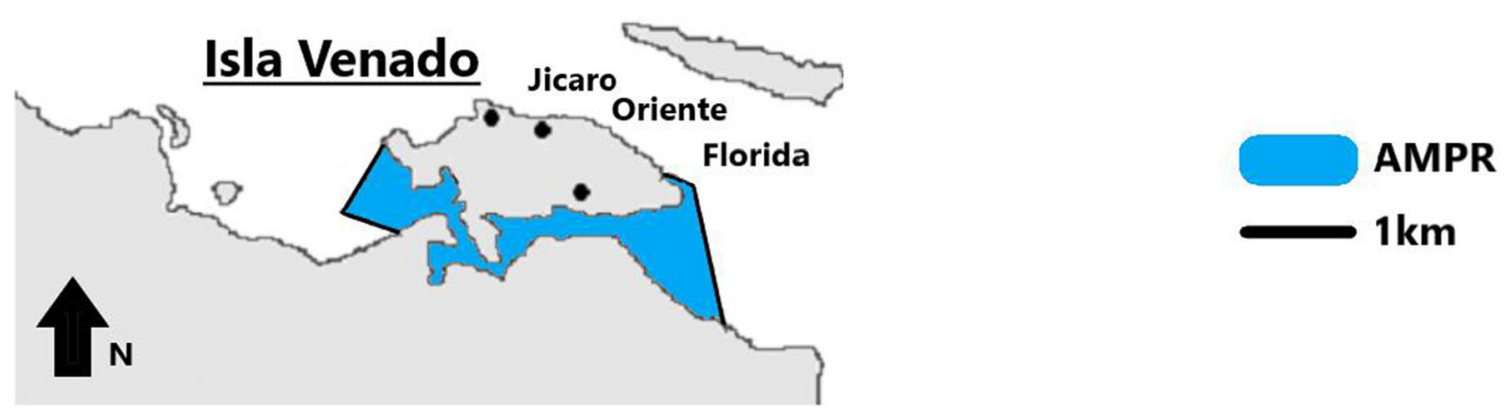

Fig. 1 (A) Map of Costa Rica in Central America, with the location of Isla Venado. (B) Map of the Gulf of Nicoya, Costa Rica. (C) Map of the Isla Venado AMPR

asking interviewees what they know about the social and ecological characteristics of the island's fisheries and AMPR, and then their perceptions of those characteristics related to AMPR governance issues (Appendix Section B). Technical terminology related to the frameworks was rephrased for interviewees, and they were not aware that questions related to a framework.

\section{Data analysis and coding process}

Our study shows how to relationally analyze qualitative data with two different frameworks. A deductive content analysis (Stemler 2001) was completed using a coding procedure categorizing the qualitative interview data into both Bennett's perception framework and the SESF. We established a consensus-based coding procedure, then the interview data was coded first by one author (AJ), then evaluated by a second author (SP) for consistency. Inconsistencies were discussed, leading to a second round of coding (AJ) resolving ambiguities.

Interviews were translated from Spanish to English and simultaneously transcribed. We conducted all coding with the qualitative data analysis software MaxQDA. Due to length, some interviews were not entirely transcribed but coded using the audio files. We drew definitions for many variables of the SESF from the Social-Ecological Systems Meta-
Analysis Database (Cox 2014; SESMAD 2014) (Appendix Section C) and a recent review of the SESF (Partelow 2018). Entire individual sentences were the units of analysis in the text transcripts. The coding was not mutually exclusive; content could be coded into several categories and both frameworks, allowing for the analysis of linkages between variables and frameworks. We then examined the isolated and co-coded content from each framework using the 'Code Relations' function in MaxQDA, with specific codes (i.e., framework variables) analyzed qualitatively and separately. We further subdivided the original four subcategories of the perception framework (Table 1) using an open coding process, letting further subcategories emerge inductively from the data, allowing further distinction of statements relating to specific perceptions. We added new sub-categories of the perception framework and synthesized the text within each (AJ and SP). We selected direct interview statements considering all content for each variable to highlight specific arguments made in each section, but also as those which broadly represent the theme.

We exported coded text segments for both the perceptions and SESF from MaxQDA using the "Code Relation Browser' function, converting the data into an adjacency matrix. We processed the data into a weighted edgelist format using R (R Core Team 2018; 'iGraph' package). Weighted edgelists with node attribute data were exported 
into Gephi (Bastian et al. 2009) for network visualization and analysis. The purpose of the quantitative network analysis is to (1) demonstrate quantitative methods for analyzing qualitative data to extract relational insights, and (2) to demonstrate how perceptions are not isolated phenomenon. We use network analysis to examine the extent of how perceptions, and the variables that relate to them in context from the SESF, are interlinked with each other in identifiable groups.

\section{Results}

\section{Links between identifiable perceptions on governance and social-ecological context}

Our findings show how perceptions regarding AMPR governance can be linked to many variables in the broader socialecological context (Figs. 2, 3A). Qualitative data can be coded to perception types and social or ecological variables with relational meaning. Actor (A) variables are the most common context and the most diversely interconnected with perception categories. Perceptions of social outcomes (PSO) and acceptability (PA) are most common. Overall, social variables (i.e., interview segments relating to social context) are the most frequent (Fig. 3B).
Our findings show interview content linked to Governance (GS) variables almost exclusively relates to perceptions about acceptability and to a lesser extent to social and ecological outcomes. Content related to Actors (A) is more varied between ecological outcomes, social outcomes and acceptability. A broader range of perceptions relate to Actors (A) compared to Governance (GS). The same can be observed for Resource Units (RU), Outcomes (O) and Interactions (I) content, where minimal content was related to perceptions of legitimacy. Similarly, minimal content was related to the Resource System (RS), Social, Economic and Political settings (S) or External Ecosystems (ECO).

A more detailed qualitative synthesis of our findings (Table 3) shows that many subcategories of perceptions can be derived. The interview content coded into each perception category from Bennett (2016) was further subdivided inductively into new categories. There are 13 subcategories derived within the perceptions of social outcomes. Five subcategories were derived within the perceptions of ecological outcomes. One subcategory related to perceptions of legitimacy, and six under the perceptions of acceptability.

We identify 25 subcategories nested within and sorted by the broader categories within Bennett's perception framework. The second-tier codes of the SESF are linked to our new subcategories of perceptions via the joint content coding process (Table 3, Fig. 3A). While these 25 subcategories are specific to this case study through inductive identification, our
Fig. 2 (A) Bay with artisanal fishing boats in Jícaro, Isla Venado. (B) Fishers and scientists discussing AMPR governance. (C) Interview with a fisher on Isla Venado. (D) Fishing boat transporting people to and from the island through the mangrove forest

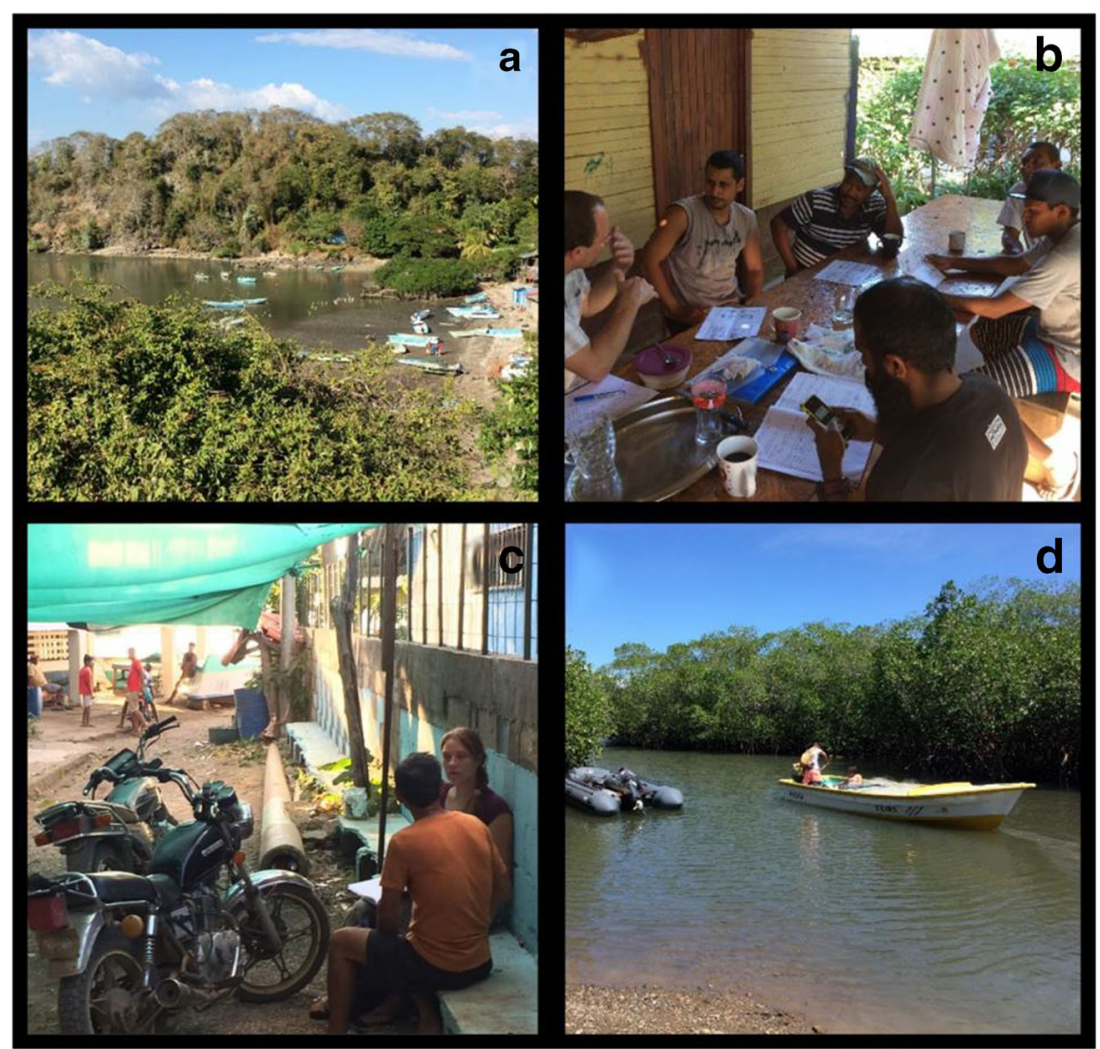


Fig. 3 (A) Relationships of cocoded qualitative data between perception categories and the context in which they were related to with the SESF variables. (B) Percentage of SESF variables influencing perceptions, aggregated from the SESF second-tier into broader 'Social variables', 'Ecological variables' and 'Interactions \& Outcomes'

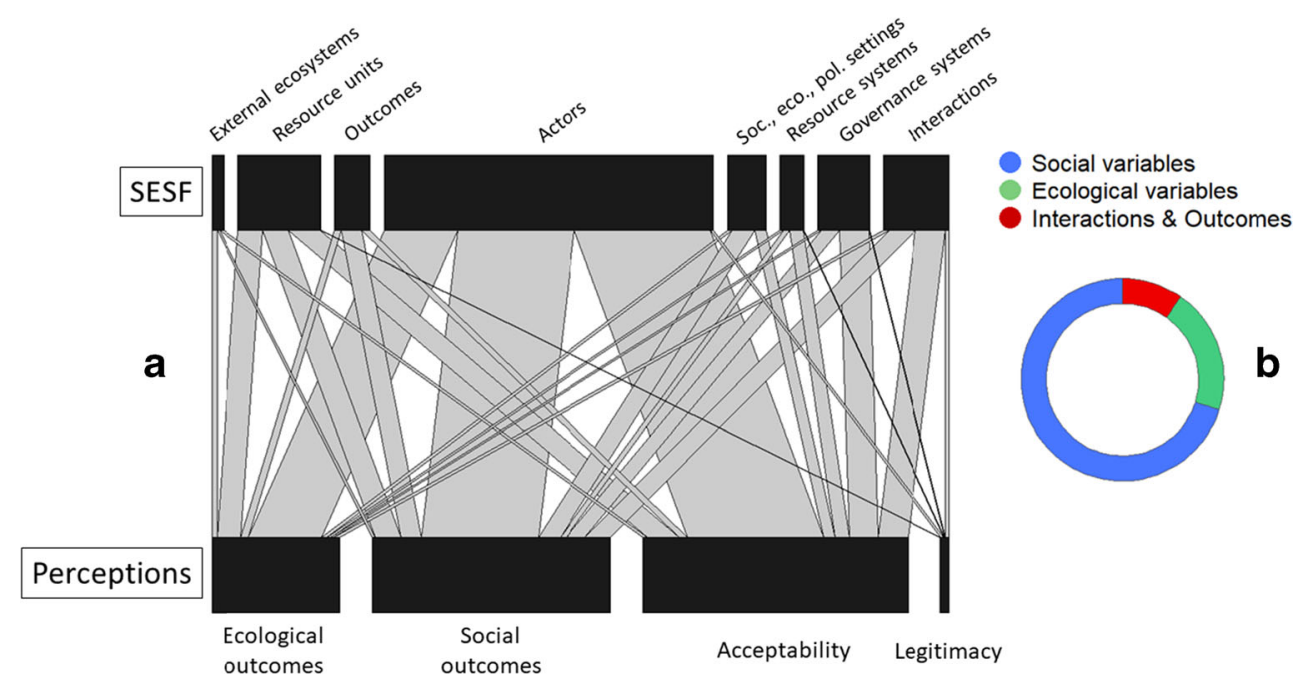

findings indicate that the relationship between different perceptions (i.e., what they are about and context they relate to) is perhaps more diverse than previously outlined in the environmental governance literature. This suggests that it is unlikely that perceptions are not singular in their relationship to the governance context of a social-ecological system. Perceptions likely relate to and potentially influence a diverse interplay of contextual variables that are both social and ecological.

Our qualitative data coding was not mutually exclusive (i.e., text segments were coded with multiple variables and frameworks). Network analyses show the frequency and cooccurrence of variables coded in the same segments for both the SESF and perceptions variables separately (Fig. 4; Fig. 5). Node degree (i.e., label size) indicates the frequency a variable is related to text segments coded with all other variables (Fig. 4C). Edge (i.e., connection) thickness indicates the frequency a variable is linked to text segments coded with only this single variable. For example, there are strong links between A3 (History and past experiences), A9 (Technologies available) and A7 (Knowledge of SES/ mental models). Interviewees frequently mentioned these three topics together (see below), gear type is linked to their fishing history and shapes current perceptions of the AMPR. The quantitative network analysis shows the overall trends in the data, and the qualitative data provide the meaning. RU7 (spatial and temporal distribution [of fish]), O2 (ecological outcomes) and A8 (Importance of resource) have high degrees. This indicates that they are often associated (i.e., mentioned together).

Overall, Actor (A) variables have the highest average node degrees, followed by Outcomes $(\mathrm{O})$, Resource Units (RU) and Resource Systems (RS) (Fig. 4A). Actor (A) variables have by far the highest 'betweeness' centrality average (Fig. 4B). Centrality scores show important nodes in terms of network connectivity. 'Betweeness' centrality calculates the number of shortest paths between all other nodes, indicating their degree of connection to others (e.g., content connectivity). Practically, the larger and more connected variables in the networks are those that are mentioned together more often. Perception codes generally co-occur less than the SESF variables (Fig. 5C), indicating that interviewees tended to mention only singular perception categories at a time (keeping in mind that individual sentences are our unit of analysis for co-occurrence). Perceptions of acceptability (PA) have the highest average degree and 'betweeness' centrality scores, followed by perceptions of social outcomes (PSO) (Figs. 5A, B).

\section{Perceptions and fisheries co-management on Isla Venado, Costa Rica}

This section contains qualitative analysis and excerpts of the case study organized by the perceptions' categories (Table 3 ). All subcategories are elaborated and included (however, for the subcategories with the least number of coded segments within each of the four main perceptions' categories (i.e., PSO1, PSO2, PSO6, PSO10, PSO11, PEO2, PEO3, PEO5, PA1, PA3) see Appendix).

\section{Social outcomes}

Perceptions of social-economic impacts of gears (PSO3) Development and adaptation have led to many gear types and fishing techniques. Historically, fishers used hand-lines, sailing or row boats, as some elders still do today. There is a perception that new gear has led to increased fishing pressure over time. In the late 1970s gillnets were introduced, and soon became the dominant gear type. Long-line fishing and artisanal bottom trawls for commercial shrimp fisheries followed. Artisanal purse seine nets are now used, allowing the enclosure of entire fish schools. Responses suggest that fishers 
Table 3 First level perception categories based on Bennett (2016). Second level perceptions categories inductively derived from findings in this study. SESF first and second-tier variables co-coded with the interview content for each perception category. Only SESF variable presence is recorded, not frequency as shown in Fig. 3

\begin{tabular}{|c|c|c|}
\hline Category of perceptions & Subcategory of perceptions & Second-tier SESF variables related to the perception \\
\hline \multirow{13}{*}{$\begin{array}{l}\text { (PSO) } \\
\text { Perceptions of social } \\
\text { outcomes }\end{array}$} & PSO1 - Perceptions of livelihoods and well-being & S2, S5, RU, RU2, RU4, RU7, A2, A3, A8, A9, I1, O1, O2, ECO1 \\
\hline & PSO2 - Perceptions of future outlook & $\begin{array}{l}\text { S1, S2, RS4, RS6, GS5, GS6, A2, A3, A4, A7, A8, A9, I7, I9, O1, } \\
\text { O2 }\end{array}$ \\
\hline & $\begin{array}{l}\text { PSO3 - Perceptions of social-economic impacts of } \\
\text { gears }\end{array}$ & S5, GS6, RU, RU2, RU4, RU6, A2, A7, A8, A9, I1, I4, I9, O1, O2 \\
\hline & PSO4 - Perceived need to fish illegally & RS6, GS5, A2, A3, A7, A8, A9, I9, O1, O2 \\
\hline & PSO5 - Perceptions of economic equality & S5, RU, RU2, RU4, RU6, A3, A7, A9, O1, O2 \\
\hline & PSO6 - Perceptions of social cohesion and trust & $\mathrm{O} 1$ \\
\hline & $\begin{array}{l}\text { PSO7 - Perceptions of self-efficacy and belief in } \\
\text { change }\end{array}$ & S2, S5, GS5, A2, A3, A7, A8, A9, I3, I4, I9, O1 \\
\hline & PSO8 - Perceptions of intergenerational conflict & S2, GS5, A2, A3, A7, A8, A9, I4, I8, I9, O1 \\
\hline & $\begin{array}{l}\text { PSO9 - Perceptions of other fishers and community } \\
\text { members }\end{array}$ & $\begin{array}{l}\text { S1, S2, S5, RS6, GS5, GS6, RU, RU2, RU4, RU6, RU7, A2, A3, } \\
\text { A4, A7, A8, A9, I1, I2, I4, I5, I7, I9, O1, O2, ECO2 }\end{array}$ \\
\hline & PSO10 - Perceptions relating to cooperation & S5, S8, GS5, RU4, A2, A3, A6, A7, A8, A9, I2, I4, I7, I9, O2 \\
\hline & PSO11 - Perceptions relating to AMPR & $\mathrm{RU}, \mathrm{A} 8$ \\
\hline & $\begin{array}{l}\text { PSO12 - Perceptions of social consequences of miss- } \\
\text { ing management input }\end{array}$ & GS5, GS6, RU4, A3, A7, A9, I4, I9, O1, O2 \\
\hline & $\begin{array}{l}\text { PSO13 - Willingness to participate in AMPR moni- } \\
\text { toring }\end{array}$ & A8, I4, O1 \\
\hline \multirow{5}{*}{$\begin{array}{l}\text { (PEO) } \\
\text { Perceptions of ecological } \\
\quad \text { outcomes }\end{array}$} & $\begin{array}{l}\text { PEO1 - Perceptions of AMPR as an effective gover- } \\
\text { nance approach for conservation }\end{array}$ & A9 \\
\hline & $\begin{array}{l}\mathrm{PEO} 2 \text { - Perceptions of environmental change and fu- } \\
\text { ture outlook }\end{array}$ & $\begin{array}{l}\text { S2, S5, RS, RS4, RS6, GS5, RU, RU1, RU2, RU4, RU5, RU6, } \\
\text { RU7, A2, A3, A4, A5, A7, A8, A9, I1, I7, O1, O2, ECO1, } \\
\text { ECO2, ECO3 }\end{array}$ \\
\hline & PEO3 - Perceptions of causes for change & $\begin{array}{l}\text { S2, RS, RS4, GS5, GS6, RU, RU1, RU7, A2, A3, A7, A8, A9, I4, } \\
\text { I7, O1, O2, ECO1, ECO2 }\end{array}$ \\
\hline & PEO4 - Perceived harmfulness of gears & RS4, GS2, GS6, A2, A7, A9, O1 \\
\hline & $\begin{array}{l}\text { PEO5 - Perceptions of environmental impacts of other } \\
\text { management approaches }\end{array}$ & GS5, RU, RU2, A3, A7, A9, I1, O1, O2, ECO3 \\
\hline \multirow{8}{*}{$\begin{array}{l}\text { Perceptions of legitimacy } \\
\text { of governance and } \\
\text { institutions } \\
\text { (PA) } \\
\text { Perceptions of governance/ } \\
\text { management acceptabil- } \\
\text { ity } \\
\text { institutions/ collective } \\
\text { action }\end{array}$} & PL1 - Legitimacy of community-based monitoring & GS5, A2, A8, I9, I4, O1 \\
\hline & & \\
\hline & PA1 - Perceived acceptability of AMPR & $\begin{array}{l}\text { S2, S5, RS, RS4, GS2, GS5, GS6, GS10, RU, RU1, RU2, RU6, } \\
\text { RU7, A1, A3, A4, A5, A7, A8, A9, I4, I5, I9, O, O1, O2, ECO3 }\end{array}$ \\
\hline & $\begin{array}{l}\text { PA2 - Perceived acceptability of other management } \\
\text { approaches (i.e. seasonal closures, gear restrictions, } \\
\text { licenses) }\end{array}$ & $\begin{array}{l}\text { S2, S8, GS5, GS6, GS10, RU, RU2, RU4, RU7, A2, A3, A7, A8, } \\
\text { A9, I1, I7, I9, O1, O2, ECO3 }\end{array}$ \\
\hline & $\begin{array}{l}\text { PA3 - Perceptions of authorities (i.e. INCOPESCA, } \\
\text { coast guards, ASLOPE) }\end{array}$ & $\begin{array}{l}\text { S1, RS, RS4, RS6, GS2, GS5, GS6, RU, RU6, RU7, A2, A3, A4, } \\
\text { A5, A7, A8, A9, I4, I5, I7, I9, O, O1, O2, ECO1 }\end{array}$ \\
\hline & PA4 - Perceptions of who should take responsibility & S1, S2, GS5, GS6, RU, RU4, RU6, A3, A7, A8, A9, I4, O1 \\
\hline & $\begin{array}{l}\text { PA5 - Perceptions of needs and governance improve- } \\
\text { ments }\end{array}$ & $\begin{array}{l}\text { S1, S2, S4, RS4, RS6, GS2, GS5, GS10, RU1, RU2, RU4, A1, A2, } \\
\text { A3, A7, A8, A9, I4, I9, O1, ECO1, ECO2, ECO3 }\end{array}$ \\
\hline & PA6 - Perceptions of cooperation & S5, GS5, RU4, A2, A3, A8, A9, I2, I7, O2 \\
\hline
\end{tabular}

perceive gear changes as a primary driver of past conflict. Artisanal purse seine nets are perceived to be a source of conflict today. Fishers reported that increased catch from these gears led to a drop in market prices, negatively influencing legal fishers who now get paid less for their smaller catches. This is perceived to drive economic inequality and community conflict. A fisher complained that: "He [referring to a purse seine fisher] goes and since he caught a thousand kilos, he doesn't care, 'I sell for a thousand (colones per kilo), that makes a million'... And I fish thirty (kilo), for me that are thirty thousand colones ... very little [...] It affects one by the prices, they lower the prices. [...] Whoever fishes legally 

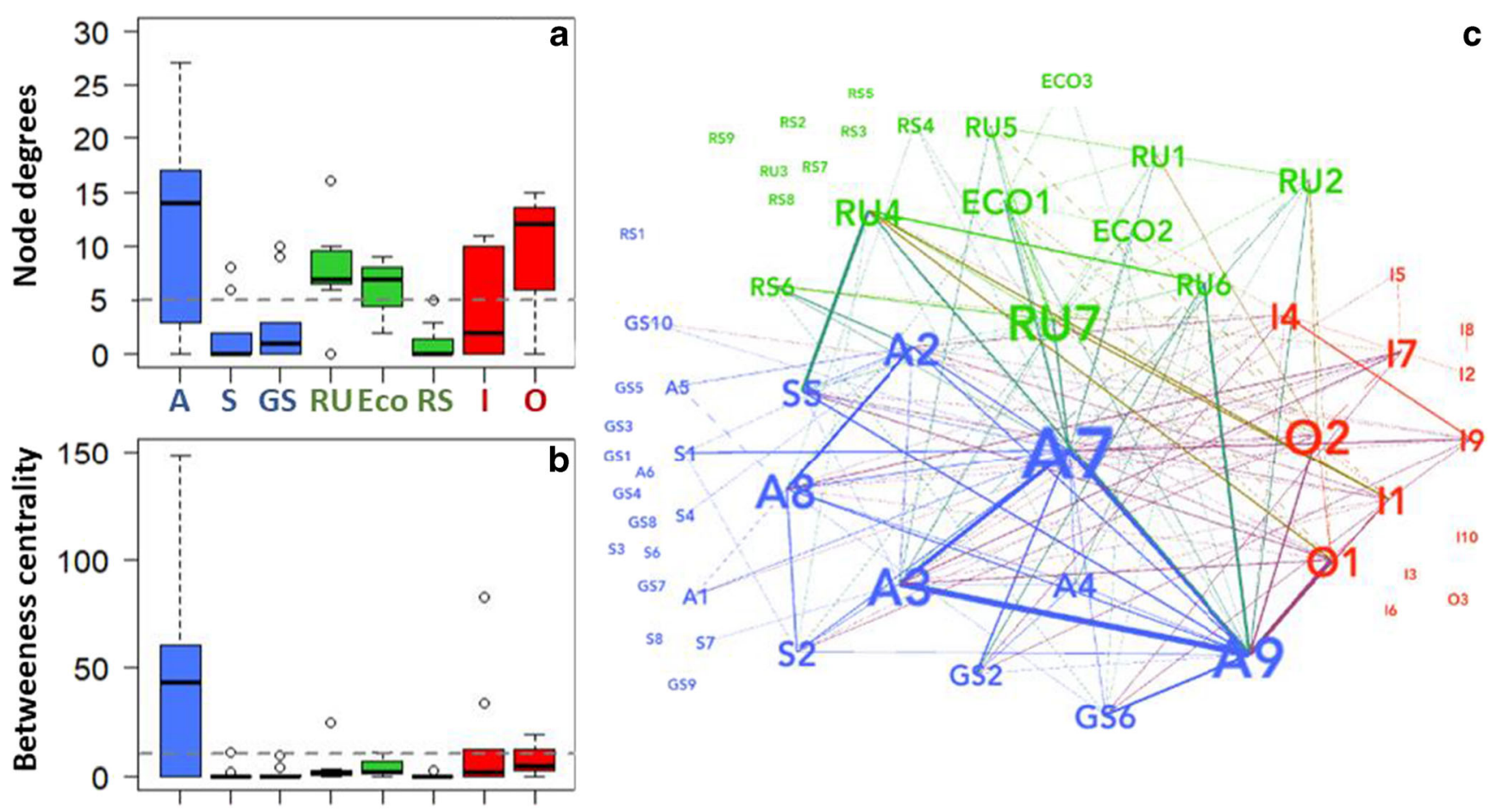

A S GS RUEco RS I O

Fig. 4 Network analysis of the relation between coded qualitative interview data with the SESF in this study. (A) Node degree distributions aggregated at the first-tier level of the SESF. (B) 'Betweeness' centrality distributions aggregated at the first-tier level of the SESF. (C) Network plot showing the relationship between SESF second-tier variables that

were coded (i.e., linked or co-occurring) in the same interview segments. Second-tier variables are colored by the first-tier variable they belong to. Node label sizes are scaled to their node degree. The network plot is undirected. SESF labels are shown in Table 2

and catches thirty kilos, gets nothing [...]". However, one fisher perceived that many benefited by purse seine nets since it required group work. Another fisher perceived that such nets decreased fish quality on the market, as there were no cooling and processing facilities for such large quantities of fish on the island. Despite high fuel costs, some interviewees perceived surrounding nets to be most profitable. In contrast to hand-line fishing, which is perceived to allow for equal benefit sharing and balanced fisheries but hardly profitable.

Perceived need to fish illegally (PSO4) A shared perception was that almost all artisanal fishers operated illegally in the Gulf of Nicoya. Several interviewees saw the need of using illegal gears to make a living. A fisher stated: "If [...] the fisher does what the law says, the fisher here does not survive. There are families that are not going to survive." Fishers described a vicious cycle of free-riding. They reported that seeing the much higher catches of others using illegal gears made them not only want to do the same but also created economic pressure. A community elder stressed, "the one who is going to fish legally is the one who suffers the consequences [...] who goes legally, captures much less, much, much less [...] now there are few, very few who go legally." Others perceived that they were forced by gear restriction policies to use other illegal gears in order to make a living, although they considered them destructive. Other community members did not perceive an economic need to use illegal gears but understood it as justification. This perception was mainly shared by non-fishers.

Perceptions of economic equality (PSO5) Fishers perceived increasing economic inequality among those using different gear types leading to conflict among community members. "One catches a lot, the other catches nothing [...] here in the Gulf of Nicoya there are those levels that one family does well, others very badly because of that way of fishing [...] there are big levels, socially [...]" (Community elder/ spiritual leader). One fisher emphasized the role of technological development, "nowadays who has the best equipment, catches the most $[\ldots]$ small and bad equipment catches less [...] in former times there was mainly hand-line fishing, so the fish was better distributed." Another fisher explained that there has always been economic inequality among fishers, but nowadays it is more noticeable as catches are more unequally distributed.

Perceptions of self-efficacy and belief in change (PSO7) Many interviewees expressed their conviction that fishers could clearly contribute to sustainable resource management with their knowledge and experience. Responses to whether they felt empowered to change their situation varied. Some 

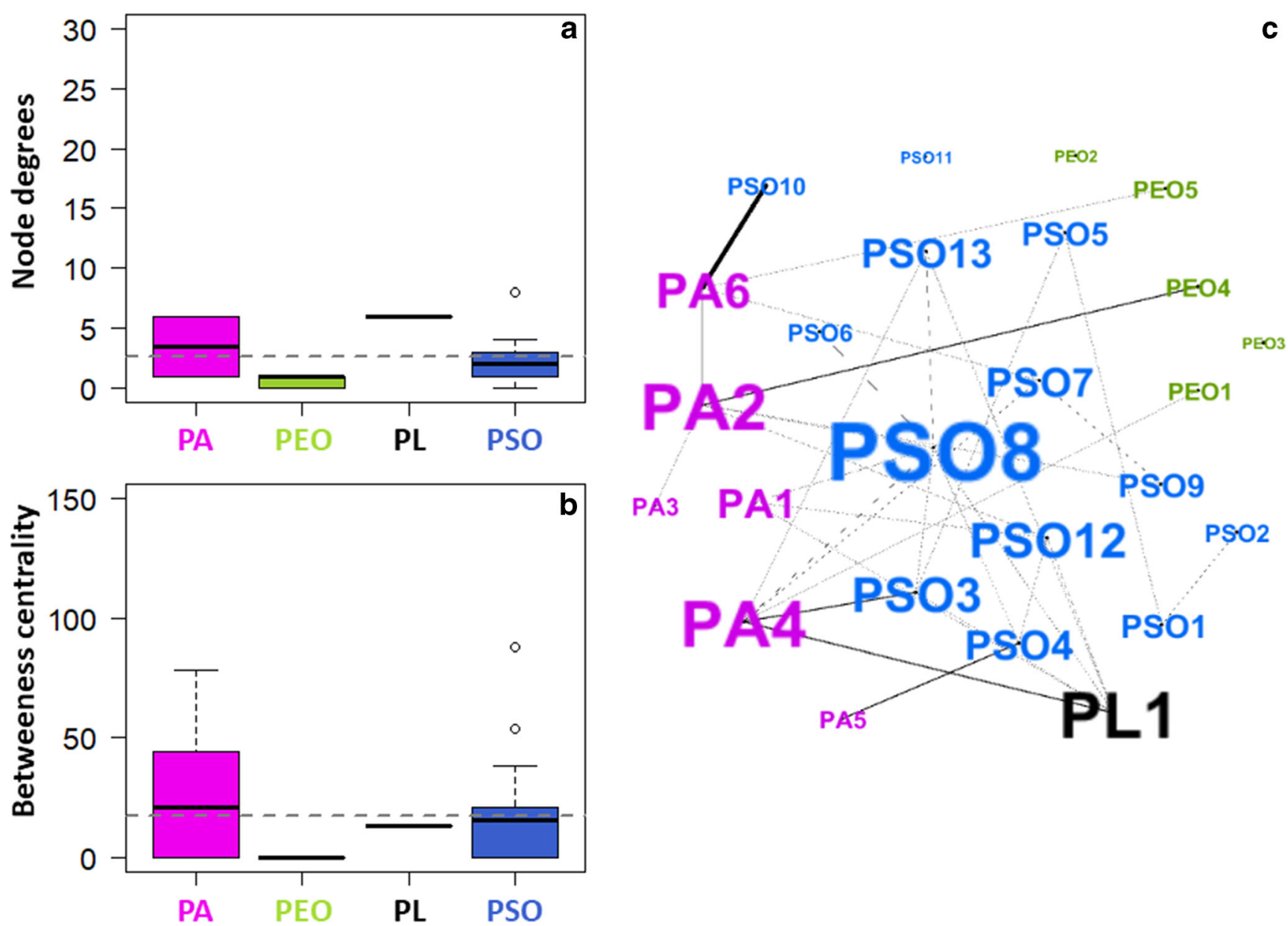

Fig. 5 Network analysis of the relation between coded qualitative interview data with the perceptions framework. (A) Node degree distributions aggregated at the first level of the perceptions framework. (B) 'Betweeness' centrality distributions aggregated at the first level of the perceptions framework. (C) Network plot of showing the relationship between interview segments coded with inductively derived second-tier

perceptions. Second-tier variables are colored by the first-tier variable they belong to. Node label sizes are scaled to their node degree. The network plot is undirected. Labels shown in Table 3. PA $=$ Perceptions of Acceptability, $\mathrm{PEO}=$ Perceptions of ecological outcomes, $\mathrm{PL}=$ Perceptions of legitimacy, $\mathrm{PSO}=$ Perceptions of social outcomes

believed that fishers have the power to influence their situation and emphasized the role of cooperation, whereas others stated that fishers faced challenges to improve their situation. A young fisher found that the intermediaries (patrons/middlemen) had much influence on the economic situation of the fishers as they set the prices. He described low product prices as one of the biggest challenges for the fishers. In general, the perception that the future was out their hands was common. Although the AMPR intends to empower and overcome this sentiment with community-based property rights and comanagement representation, the problems are perceived as external and not able to be fixed by local collective action by many.

Perceptions of intergenerational conflict (PSO8) These interviews suggest that there has been a shift in awareness of conservation and resource use between older and younger community members, with the perception that mainly young

people used illegal and destructive gear. They were considered selfish, not thinking long-term or about community wellbeing, and ignorant about older people. This perception was mainly shared by older people. However, others stressed that older people often do not depend directly on fishing any longer, also stating that $65 \%$ of the community members were younger than 35 years old (Caja Costarricense de Seguro Social (CCSS) 2016). Others believed that there was no difference between ages regarding illegal gear use. The president of a youth group said that especially older people did not believe in the youth or cooperation and would not change anything: "They say that they (older people) believe in their own children. They don't believe in anything. They lived in a time when they wanted to form several cooperatives. They [fell apart] because the people who were there [...] didn't want anything more [than] to see how they stole money. Although, it sounds ugly [...] that is the reality. [...] But all organizations such as cooperatives fail because of it [...] people want to earn 
more than others." He continued: "Young people have more a developmental thinking, in terms of tourism, [...] there are several alternatives. The thing is that we do not [know] how to develop them [...] so we have to do the same as our parents do. We have to fish." Another young fisher emphasized the need for dialogue between generations because he thought that older people had more experience, but young people had ideas and were willing to change some things.

Perceptions of other fishers and community members (PSO9) Interview responses showed that other members of the fishing community were often perceived as being selfish, which was seen to cause conflicts, to disunite the community, and as a reason why people fish illegally, and overall why the AMPR was not working well despite community property rights and co-management involvement on paper and efforts by many to foster collective action. A fisher stated: "So that is why I tell you there will pass generations and I calculate that the fisher is never going to unite because the fisher is very disunited in that. Each one catches for himself and does not look after others, in that sense." Further, common perceptions were a lack of long-term thinking, seen as a motivational challenge to engage, for example, in conservation projects. Also, perceptions that fishers were not willing to take responsibility, but were waiting for help from outside. The president of a youth group stated: "The people of the island are used to not working. They want everything to be done by someone else. We want to change that mentality. [...] You do not have to wait for someone to come from outside." People expressed that they have lost trust in community members and perceived them as not being honest. One fisher stated that everybody thinks differently with different interests leading to a major source for conflict inhibiting cooperation towards AMPR implementation. A member of the local fishing association ASLOPE said: "People, each thinks differently, so [...] it is hard to agree." He continued: "[...] Some use artisanal bottom trawls, that is forbidden, then others are going to use purse seine nets, that is forbidden, so everyone has their own way of thinking, if that generates money then he is not going to stop it, very easy, you see? So that is why it is difficult". Another source of conflict was perceived to be competition between fishers. One fisher said that fishers have a destructive attitude in general because fishing itself is destructive. However, generally interviewees reported that people were trying to avoid conflicts despite many statements explicitly highlighting their role.

Perceptions relating to social consequences of missing management input (PSO12) A lack of management, particularly the lack of monitoring and sanctioning of illegal fishing, has led to a perceived loss of trust in governmental agencies. As a consequence, many perceived no political willingness to improve living conditions of fishers, and overall, interviewees did not feel supported. A fisher stated: "They are not interested in doing it well (referring to seasonal closures), and when the time comes for political campaigns, this country is in chaos. Nobody wants to lose the voice of a fisher [...] the fisher has lost respect for the law." Another stated: "When you try to do things, you are demotivated because when you arrive at the institutions they don't take care of you as it should be [...] even we have been meeting with the Minister of Economy to discuss the issue of the Gulf of Nicoya and that day I came out so demotivated $[. .$.$] because the gentleman at no time raised$ something new for us but he was dedicated to the telephone and didn't listen to the proposal we put forward. So that demotivates [...] an important person who is in his power to say something, in the government, has to see a vision."

Willingness to participate in AMPR monitoring (PSO13) Fishers and members of ASLOPE reported that they have become discouraged over time and have stopped reporting illegal fishing within the AMPR during seasonal closures due to lack of support from the Coast Guard and INCOPESCA. They felt alone in implementing the AMPR. A leader of ASLOPE stated: "They gave us a baby (the AMPR) but did not show us how to take care for it." Others were concerned about interfering in violent conflicts and problems with family and community members. These were reasons why many interviewees could not imagine participating in community-based monitoring without being authorized, trained and compensated. A fisher asked whether he could imagine monitoring the AMPR responded: "Yes, of course, as long as I'm protected by law [...] I have not taken care of it because it is dangerous [...] if someone interferes to tell a person, look, don't throw out your gillnet there, because that's a responsible fishing area, and we want to take care of it [...] God forbid". However, especially young fishers seemed to be willing to participate. Fishers are deterred from monitoring their peers due to fears of retribution because many fishers use different gears despite the rules and have differing opinions about how the AMPR should have been established. Others feel they have not been included and are being told to change their fishing practices to survive under economic hardship.

\section{Ecological outcomes}

Perceptions of AMPR as an effective governance approach for conservation (PEO1) The AMPR was generally perceived as an appropriate conservation management approach for three reasons. First, mandating selective fishing gear (i.e., hand-line fishing); second, an expected reduction of fishing pressure due to new opportunities for additional income from tourism; and third, the protection of nursery grounds (i.e., mangroves). However, interviewees felt that responsible fishing ensuring growth and reproduction of targeted species was not practiced 
in the Gulf of Nicoya. The perception of expected recovery time for an AMPR varied from a few months (3-4 months, as for the seasonal closures) up to several years (2-4 years). Many view the AMPR as a useful idea, but few perceive there to be practical changes associated with their implementation to improve the ecological situation needed for fishing.

Perceived harmfulness of gears (PEO4) Hand-lines were perceived to cause less environmental harm due to high selectivity. They are historically associated with former abundant and balanced fisheries. Artisanal purse seine nets, artisanal bottom trawls and small-meshed gillnets are considered the most destructive gear types because of low selectivity, high by-catch, large landings, and a high proportion of caught juvenile fish. However, perceptions were not homogeneous. Especially the use of artisanal purse seine was in part linked to perceived resource scarcity and expected fisheries collapse. Fishers who used long-lines perceived them as selective and hence not very destructive.

\section{Legitimacy of community-based monitoring (PL1)}

Monitoring and rules enforcement of the AMPR is legally shared by the Coast Guard and ASLOPE, while INCOPESCA serves as an intermediary between them. Fishers who were engaged in the community-based monitoring of the AMPR had to receive capacity building training. However, members of ASLOPE reported feeling unqualified and unauthorized to control other fishers because of a lack of necessary training. A member of ASLOPE who was involved in the AMPR planning process stated: "We had (referring to a community-based monitoring) the people, but we needed that they do a training that helps in what we have to do. They never did that. $[\ldots]$ If you are going to fish illegally there (referring to AMPR) I can't tell you don't do that [...] then that has been our problem." Another member of ASLOPE described fishers engaged in monitoring as facing the challenge that they were not perceived as having authority by other community-members: "The same fishers control the other fishers? No, that would create conflict. [...] Responsible for that are the authorities. [...] as I do not have how to say that I am an authority from the government, then you do not listen to me ..." Fishers do not view themselves or other fishers as legitimate authorities for enforcing AMPR rules, and largely expect external government agencies with very limited capacity to enforce daily fishing activities to do this. Although the move towards community-based rights and responsibilities for fishing is viewed as a good idea by many, fishers tend to still view governance as government despite efforts to partially transfer those responsibilities to themselves.

\section{Acceptability}

Perceived acceptability of other management approaches (PA2) Overall, seasonal closures were considered an effective management practice because of rapidly increasing fish abundance afterwards. However, fishers stated that financial aid during closures is insufficient. Some fishers also expressed their concern about a complete closure of the Gulf of Nicoya. Only fishers with a license receive financial aid during seasonal closures. A large number who did not have a license nevertheless were dependent on fisheries. Young people were affected because licenses had recently stopped being issued to limit the number of fishers. Fishers often left the island to seek temporary employment or kept fishing during the closure. Hence restricting fishing licenses was perceived to be a driver for illegal fishing. Furthermore, people were concerned that management decisions were made based on statistics that omit the estimated high rate of unreported landings by fishers without licenses: "They manage by mistake [...] only Isla Venado has 1000 inhabitants and those [...] depend on going to sea and Isla Venado has about 200 and something people with licenses. So it means that some 600 people are fishers without a permit $[. .$.$] where is the control$ exercised by the institution? We are worried about that because when they give us a statistic [...] it says that it is surpassing what should be exploited in the gulf. It alarms us with only that number, and those that are not reported."

Fishers using different gears had different perceptions and reasons for which gears should be allowed. Some supported banning all gear except hand-lines. Others stated that gear restrictions were not based on previous studies but were a result of conflicts among fishers using different gears: "The fisher has never been able to unite, [...] that is why there are so many laws, because if you are taking out a lot of fish with one gear, there is another that is uncomfortable, another fisher himself is uncomfortable that you take out a lot, then he goes and accuses you, and they hold a meeting to ban that gear. And so that is why they put many laws against the same fisher, because the fisher never agrees with the ideas of another." Others perceived gear restrictions as driving factor for illegal fishing and increased fishing pressure on single species: "Because the truth is, illegal gears come by the same restrictions [...] INCOPESCA has done. So [...] tell me how do you survive? So INCOPESCA in doing that, forces the fishers to use other gear that would not be very convenient. But unfortunately, it forces them to do so." Acceptability of the AMPR is viewed negatively in reference to gear restrictions and seasonal closures as rules, largely because they are perceived not to match the social and economic reality faced by fishers, or the historical fishing norms around past conflicts between gear types. 
Perceptions of who should take responsibility (PA4) Many informants stated responsibility for improving the fisheries lay outside the community: "To solve those things, $[\ldots]$ the government, but [...] the government puts people who don't know the sea. And they are the ones who make the laws [...] the only way, as I tell you, the government can [...] look for fishing alternatives. [...] But if they don't do that, it's difficult." Several interviewees saw the main responsibility for the fisheries in governmental institutions, mainly INCOPESCA and the Coast Guard. However, fishers felt that the shared responsibilities and authorities between INCOPESCA and the Coast Guard was unclear: "And it is that I have told the fishers, look, change the mesh sizes, use other meshes, use the good mesh for the fish, and they get angry, so I can't do anything, the one who has to act here is INCOPESCA and the Coast Guard [...] INCOPESCA says they're not a priority, it's up to the Coast Guard, and the Coast Guard says they don't have permission to come and pick it up, they need to resolve it at sea. So I don't understand how far they are, how they know each other to do things." Others expressed the view that fishers themselves would have to become active and aware in order to improve their situation, while some felt that fishers and governmental agencies share responsibilities for marine resource governance. Especially Governmental agencies were seen to have primary responsibility for control and sanction infringements: "I believe it is about becoming selfaware [...] It's about the fishers, because that is not, neither authorities, neither the government nor anything, that has to come from the same fishers, to agree all to [...] take care of what gives us to eat, because the truth [...] it is a matter of the fishers."

\section{Perceptions of needs and governance improvements (PA5)}

Many people saw the need for developing economic alternatives on the island, i.e., aquaculture, tourism, and recreational fishing. However, a fisher pointed out that the development of tourism would not benefit the whole community equally: "Here they say to the people: 'Don't worry, tourism will give you.' [...] It's not so easy because if I don't have [anything] to sell to the tourist what is the tourist going to buy from me [...] but with what means are we going to do it? [...] In the end [...] they're going to see those services but it's going to be people who have, and with what? [...] Nothing is going to sustain the life of everyone, it is going to sustain the life of who is prepared to live from it. Those of us who don't prepare ourselves won't live off it."

Most considered education to be very important and a way for young people to become independent from the fisheries and improve their living conditions. At the time of this study, getting a university degree or working outside fisheries would have meant leaving the island: "[...] For one who stops fishing there are 20 who start fishing if they do not look for another way of life which is [studying]. Because no one is going to live from anything that is not there. First [studying], I would tell anyone to go to the city, apply for a job and present that they barely know how to write [...]."

Others stated they would need help and financial support to be able to improve their situation as well as enforcement of rules. Some perceived a need for environmental protection. Many fishers expressed their hope to get more involved in fisheries management and decision-making: "For me it would be better that INCOPESCA takes the effort to come to talk to fishers or to support with the biologists. I guarantee you that if INCOPESCA as a large institution that is for the fishers, would unite more with the fishers, it would be a different reality here in fisheries [...], fisheries would be balanced. There would be no need for illegal gear." Overall, acceptability of the AMPR is often positioned in contradiction to the social, economic, and cultural reality of the fishers on the island. The many reasons given for why it is agreed to be a good idea but not accepted as a viable practical solution is this perceived mismatch and need for external capacity.

\section{Policy challenges for fisheries co-management on Isla Venado}

Acceptability of the AMPR was the most important governance issue on Isla Venado. While the AMPR is largely viewed a legitimate policy concept, its effectiveness in the local context brought more diverse perceptions, particularly on the roles and responsibilities of different actors.

Fishers tend to form groups and opinions based on the gear type they use shaping how they view themselves and others, including their reasons for fishing, perceived economic benefits, acceptability of the AMPR and its rules. As small-scale fisheries are often multi-species multi-gear livelihoods generally (FAO 2015), and in the region (Carrillo et al. 2019), gear heterogeneity drives governance challenges, or at least perceptions of what those challenges are and who should be responsible for dealing with them.

Overall, the concept of the AMPR is accepted. However, conflicts over location and boundaries originate from the minimal inclusion and participation of community members during planning processes. ASLOPE represents only a small percentage of fishers, mainly from one of the three communities, creating challenges for organizing, communicating, and resolving conflicts between all those involved in the fishery difficult due to the lack of constructive space for deliberation. These fueled perceptions about 'the others', their own contributions to the problems, while simultaneously giving the excuse to remove responsibility from those same individuals. Similarly, while most complained that the government was a main problem for AMPR implementation, they also recognized that cooperation among the island's stakeholders in taking self-responsibility was not working. 
Carrillo et al. (2019) have shown that without collective action through communication and deliberative processes, AMPRs will struggle to overcome challenges with other gear users, the government agencies, and other community members. Combined with the generally low acceptance of ALSOPE on Isla Venado, a sense of ownership and collective responsibility has largely failed to develop. Capacity building should be coupled with AMPR design to ensure co-learning and adaptive capacity within and between groups involved.

As a policy approach, AMPRs in Costa Rica are a step towards inclusion and empowerment in the small-scale fisheries sector (Sabau 2017). They can be viewed as an attempt to implement the FAO Voluntary Guidelines for Securing Sustainable Small-Scale Fisheries in the Context of Food Security and Poverty Eradication (FAO 2015; Jentoft et al. 2017). However, our findings suggest that establishing policies is only the first step in a process that requires continual capacity building and co-learning for long-term success. Seven AMPRs exist in the Gulf of Nicoya, all with different challenges and degrees of success (Lozano and Heinen 2015; Rivera et al. 2017; Sabau 2017; Carrillo et al. 2019). Our study supports the conclusions of this literature that progress will require providing fishing communities with capacity building support from associated government agencies (e.g., INCOPESCA, the Coast Guard), training on how to organize administrative and financial matters, building shared norms, as well as the integration of deliberation and co-learning into policy processes in a constructive and transparent way (Partelow et al. 2019). This would address the perceived lack of social cohesion and trust among community members who form perceptions and often communicate but do not see this reflected in policy processes or actions. These are further reinforced by observed inequalities and unresolved conflicts over gear, zoning, and enforcement roles.

More specifically, the feeling of being capable of changing something was low, due to past failures and conflicts. Another challenge seems to be the time-lag between the implementation of the AMPR and the socio-economic benefits to local communities. The AMPR was both an opportunity and a burden to satisfy daily socio-economic needs through fishing. This highlights the importance of developing alternative livelihoods through non- or less extractive sustainable tourism options, and financial support for the transition period, where inefficiencies and investments are needed to convert the island's economy and update its infrastructure for waste management, electricity, and drinking water.

\section{Discussion and Conclusion}

Many social and ecological variables can influence a wide range of perceptions in fisheries co-management. Our study provides two broad insights. The first is exploring how to combine two previously separate frameworks, adding value both conceptually and empirically to the study of perceptions in natural resource co-management. We show how different qualitative data collection and analysis methodologies, including the quantitative network analysis of qualitative data, are useful as a first step towards unpacking the richness and density of potential links between existing perceptions and socialecological system context. We have done so by using multiple methodologies to analyze qualitative data, unpacking the many meanings embedded in descriptive qualitative data that can often be complex and difficult to interpret and explain. We argue there is a need to expand our toolbox of interdisciplinary data analysis techniques by exploring different ways to interpret, format, and analyze qualitative data (Pokorny et al. 2018; Alexander et al. 2019; Bodin et al. 2019).

Our combination of frameworks is an attempt to link similar but separate bodies of knowledge in environmental governance literature. Seeing how data can be coded and interpreted in both, and then compared, demonstrates the potential for extracting more diverse insights that might otherwise be limited to a singular perspective. There are a range of social-ecological systems frameworks (Binder et al. 2013; Pulver et al. 2018) and a similar diversity in environmental psychology (Steg and Vlek 2009), where we believe future research could explore the connections between them in environmental governance contexts. As we have shown, this may help reveal novel patterns in data to help better interpret human-nature relationships. We also believe our study shows the usefulness of interdisciplinary analysis, and how it can be done methodologically. Quantifying our qualitatively coded data can help assess broader patterns in the data that qualitative analysis alone might miss or ignore. Neither is a substitute for the other, each has its own value. However, when combined, both broader trends in the data and contextual richness can be inferred.

Combing frameworks can help improve the development of both, as suggested by our findings. For the SESF, variables related to knowledge and mental models (Actors; A7) specifically. The relationship between the two variables within this can be seen in different ways. Bennett's framework could be viewed as the third tier of variables of the SESF - A7. Or it could sit in the center of the SESF, as the action situation unit of analysis, looking at how all other SESF variables influence perceptions. Similarly, Bennett's framework could be expanded. We identified 25 potential subcategories of perceptions related to our case study. The degree to which these are generalizable is unknown, but it opens potential for future studies to do the same, and then compare which may be similar or different across cases. Furthermore, our study builds on existing literature focused on perceptions on the evaluation, design, and improvement of conservation management (Cinner and Pollnac 2004; Paloniemi and Vainio 2011; Bennett 2016; Beyerl et al. 2016; Gelcich and Keeffe 2016; 
Gorris 2016; Katikiro and Mahenge 2016; Pyhälä et al. 2016; Rohe et al. 2017; Turner et al. 2018; Ward et al. 2018; Glaser et al. 2018; Nzau et al. 2018), stock assessments (Leenhardt et al. 2016), collective action (Kitolelei and Sato 2016), the assessment of vulnerabilities and adaptation capacities to environmental change (Lindell et al. 2014; Koenigstein et al. 2016), specific policy strategies (Mcclanahan and Abunge 2016; Sullivan et al. 2017), and environmental values (Raymond et al. 2009; Simpson et al. 2016).

One key finding of our study is that not all contextual (i.e., SESF) variables are equally influential in regard to both the types of perceptions they may be associated with or the frequency (i.e., degree) they are mentioned. Future research could examine if our more prevalent variables are similar in other case contexts and if general patterns exist. For example, which variables (social or ecological) are more commonly associated with perceptions of governance acceptability compared to outcomes. We believe this research may help link environmental psychology, behavioral economics, and environmental governance.

A second key finding is that perceptions are often associated with many different aspects of a context, both social and ecological that do not appear to linked to specific or singular events or contexts, particularly between individuals. It seems intuitive that perceptions are shaped, in our case, by the continued experience of fishing overtime, interactions with other actors, and the ecological context within which fishing takes place in their community and region. We believe our network analysis plots are a useful method for presenting clearly the interconnected nature of the thoughts, opinions, experiences, and ultimately perceptions, of fishers in this community.

Supplementary Information The online version contains supplementary material available at https://doi.org/10.1007/s10745-021-00228-X.

Acknowledgements This study would not have been possible without the willingness of individual fishers, their families, and communities to participate in our research. We are grateful for their generosity with their time and information about their lives. We acknowledge and are grateful for general support from the Leibniz Centre for Tropical Marine Research (ZMT) in Germany and the Centro Agronómico Tropical de Investigación y Enseñanza (CATIE) in Costa Rica. We would like to thank Isis Ivania Chavez Carrillo for assistance and support in the field, as well as Roger Ballestero Madrigal. We would like to thank editorial staff at the journal for helping to improve clarity and format the manuscript.

Funding Open Access funding enabled and organized by Projekt DEAL.

Compliance with Ethical Standards The authors declare no conflicts of interest in relation to this research. Approval for research was given by the Leibniz Centre for Tropical Marine Research in compliance with ethics for good scientific practice outlined by the Germany Research
Foundation (DFG). All interviewees were informed of the study and its purpose, and then gave consent to participate before each interview.

Open Access This article is licensed under a Creative Commons Attribution 4.0 International License, which permits use, sharing, adaptation, distribution and reproduction in any medium or format, as long as you give appropriate credit to the original author(s) and the source, provide a link to the Creative Commons licence, and indicate if changes were made. The images or other third party material in this article are included in the article's Creative Commons licence, unless indicated otherwise in a credit line to the material. If material is not included in the article's Creative Commons licence and your intended use is not permitted by statutory regulation or exceeds the permitted use, you will need to obtain permission directly from the copyright holder. To view a copy of this licence, visit http://creativecommons.org/licenses/by/4.0/.

\section{References}

Alexander, S. M., K. Jones, N. J. Bennett, A. Budden, M. Cox, M. Crosas, E. T. Game, J. Geary, R. D. Hardy, J. T. Johnson, S. Karcher, N. Motzer, J. Pittman, H. Randell, J. A. Silva, P. P. da Silva, C. Strasser, C. Strawhacker, A. Stuhl, and N. Weber. 2019. Qualitative data sharing and synthesis for sustainability science. Nature Sustainability.

Bastian, M., S. Heymann, and M. Jacomy. 2009. Gephi: an open source software for exploring and manipulating networks. International AAAI Conference on Weblogs and Social Media.

Bennett, N. J. 2016. Using perceptions as evidence to improve conservation and environmental management. Conservation Biology 30(3): 582-592.

Beyerl, K., O. Putz, and A. Breckwoldt. 2016. The Role of Perceptions for Community-Based Marine Resource Management. Frontiers in Marine Science 3(238).

Biel, A., and J. Thøgersen. 2007. Activation of social norms in social dilemmas : A review of the evidence and re $\mathrm{X}$ ections on the implications for environmental behaviour 28:93-112.

Binder, C., J. Hinkel, P. W. G. Bots, and C. Pahl-Wostl. 2013. Comparison of frameworks for analyzing social-ecological systems. Ecology and Society 18(4):26.

Bodin, Ö., S. M. Alexander, J. Baggio, M. L. Barnes, R. Berardo, G. S. Cumming, L. Dee, A. P. Fischer, M. Fischer, M. Mancilla-Garcia, A. Guerrero, J. Hileman, K. Ingold, P. Matous, T. H. Morrison, D. Nohrstedt, J. Pittman, G. Robins, and J. Sayles. 2019. Improving network approaches to the study of complex social-ecological interdependencies. Nature Sustainability 2(7):551-559.

Bouma, J., and E. Ansink. 2013. Forest Policy and Economics The role of legitimacy perceptions in self-restricted resource use : A framed fi eld experiment it. Forest Policy and Economics 37:84-93.

Cárdenas, J.-C., and E. Ostrom. 2004. WHAT DO PEOPLE BRING INTO THE GAME: EXPERIMENTS IN THE FIELD ABOUT COOPERATION IN THE COMMONS. Page CGIAR Systemwide Program on Collective Action and Property Rights.

Carmenta, R., A. Zabala, W. Daeli, and J. Phelps. 2017. Perceptions across scales of governance and the Indonesian peatland fi res. Global Environmental Change 46(July):50-59.

Carrillo, I. I. C., S. Partelow, R. Madrigal-ballestero, A. Schlüter, and I. Gutierrez-montes. 2019. Do responsible fishing areas work? Comparing collective action challenges in three small-scale fisheries in Costa Rica. International Journal of the Commons 13(1):748777.

Cinner, J. 2018. How behavioral science can help conservation. Science 362(6417):889-891. 
Cinner, J. E., and R. B. Pollnac. 2004. Poverty, perceptions and planning: Why socioeconomics matter in the management of Mexican reefs. Ocean and Coastal Management 47(9-10):479-493.

Colding, J., and S. Barthel. 2019. Exploring the social-ecological systems discourse 20 years later. Ecology and Society 24(1).

Cox, M. 2011. Advancing the diagnostic analysis of environmental problems. International Journal of the Commons 5(2):346-363.

Cox, M. 2014. Understanding large social-ecological systems: Introducing the SESMAD project. International Journal of the Commons 8(2):265-276.

Delgado-Serrano, M. M., E. Oteros-Rozas, P. Vanwildemeersch, C. Ortíz-Guerrero, and S. London. 2015. Local perceptions on socialecological dynamics in Latin America in three community-based natural resource management systems. Ecology and Society 20(4).

Dickman, A. J. 2010. Complexities of conflict: The importance of considering social factors for effectively resolving human-wildlife conflict. Animal Conservation 13(5):458-466.

FAO. 2015. Voluntary Guidelines for Securing Sustainable Small-Scale Fisheries in the context of Food Security and Poverty Eradication. Page Fao.

Fargier, L., H. J. Hartmann, and H. Molina-Ureña. 2014. Marine Areas of Responsible Fishing: A Path Toward Small-Scale Fisheries CoManagement in Costa Rica? Perspectives from Golfo Dulce. Pages 155-179 Fisheries Management of Mexican and Central American Estuaries.

Gelcich, S., and J. O. Keeffe. 2016. Emerging frontiers in perceptions research for aquatic conservation. Aquatic Conservation: Marine and Freshwater Ecosystems 26:986-994.

Glaser, M., P. Gorris, B. P. Ferreira, and A. Breckwoldt. 2018. Analysing ecosystem user perceptions of the governance interactions surrounding a Brazilian near shore coral reef. Sustainability (Switzerland) $10(5)$.

Gorris, P. 2016. Deconstructing the Reality of Community-Based Management of Marine Resources in a Small Island Context in Indonesia. Frontiers in Marine Science 3(120).

Grunblatt, J., and L. Alessa. 2017. Role of perception in determining adaptive capacity: communities adapting to environmental change. Sustainability Science 12(1):3-13.

Iftekhar, S., and D. J. Pannell. 2015. "Biases" in Adaptive Natural Resource Management. Conservation Letters 8(6):388-396.

Jentoft, S., R. Chuenpagdee, M. J. Barragán-Paladines, and N. Franz. 2017. The Small-Scale Fisheries Guidelines: Global Implementation. Springer.

Jones, N. a., H. Ross, T. Lynam, P. Perez, and A. Leitch. 2011. Mental Model an Interdisciplinary Synthesis of Theory and Methods. Ecology and Society 16(1):46-46.

Katikiro, R. E., and J. J. Mahenge. 2016. Fishers' perceptions of the recurrence of dynamite-fishing practices on the coast of Tanzania. Frontiers in Marine Science 3(NOV):1-14.

Kinzig, A. P., Pa. R. Ehrlich, Lee J. Alston, Ke. Arrow, S. Barrett, Gretchen C. Da., Timothy G. Buchman, Br. LEvin, S. LEvin, M. OPPEnhEimER, E. OstRom, and D. SAARi. 2013. Social Norms and Global Environmental Challenges: The Complex Interaction of Behaviors, Values, and Policy. BioScien 63(3):164-175.

Kitolelei, J. V., and T. Sato. 2016. Analysis of perceptions and knowledge in managing coastal resources: A case study in Fiji. Frontiers in Marine Science 3(SEP):1-12.

Leenhardt, P., M. Lauer, R. M. Moussa, S. J. Holbrook, A. Rassweiler, R. J. Schmitt, and J. Claudet. 2016. Complexities and uncertainties in transitioning small-scale coral reef fisheries. Frontiers in Marine Science 3(MAY):1-9.

Lindell, L., M. Henningsson, K. Marquardt, and M. E. Åström. 2014. Farmers' (local and colonists) perceptions of environmental changes in the forest frontier of the upper Amazon, Peru. Int. J. Agricultural Resources, Governance and Ecology 10(4):394-418.
Lindsay, P. H., and D. A. Norman. 2013. HUMAN INFORMATION PROCESSING: An Introduction to Psychology. Academic Press.

Lozano, A. J. G., and J. T. Heinen. 2015. Identifying Drivers of Collective Action for the Co-management of Coastal Marine Fisheries in the Gulf of Nicoya, Costa Rica. Environmental Management:1-11.

Lozano, A. J. G., and J. T. Heinen. 2016. Property relations and the comanagement of small-scale fisheries in Costa Rica: Lessons from Marine Areas for Responsible Fishing in the Gulf of Nicoya. Marine Policy 73:196-203.

Lubell, M. 2002. Environmental activism as collective action. Environment and Behavior 34(4):431-454.

Lubell, M. 2003. Collaborative institutions, belief systems, and perceived policy effectiveness. Political Research Quarterly 56(3):309-323.

Matta, J. R., and J. R. R. Alavalapati. 2006. Perceptions of collective action and its success in community based natural resource management : An empirical analysis. Forest Policy and Economics 9:274 284.

Mcclanahan, T. R., and C. A. Abunge. 2016. Perceptions of fishing access restrictions and the disparity of benefits among stakeholder communities and nations of south-eastern Africa. Fish and Fisheries 17(2):417-437.

McGinnis, M. D., and E. Ostrom. 2014. Social-ecological system framework: Initial changes and continuing challenges. Ecology and Society 19(2):30.

Molina-Terrén, D. M., A. Cardil, and L. N. Kobziar. 2016. Practitioner Perceptions of Wildland Fire Management across South Europe and Latin America. Forests:1-13.

Nelson, K. M., S. Partelow, and A. Schlüter. 2019. Nudging tourists to donate for conservation: Experimental evidence on soliciting voluntary contributions for coastal management. Journal of Environmental Management 237(December 2018):30-43.

Nyborg, B. K., J. M. Anderies, A. Dannenberg, T. Lindahl, C. Schill, M. Schlüter, W. N. Adger, K. J. Arrow, S. Barrett, S. Carpenter, F. Stuart, C. Iii, A. Crépin, G. Daily, P. Ehrlich, C. Folke, W. Jager, N. Kautsky, S. A. Levin, O. J. Madsen, S. Polasky, M. Scheffer, E. U. Weber, J. Wilen, A. Xepapadeas, and A. De Zeeuw. 2016. Social norms as solutions. Science 354(6308):42-43.

Nzau, J. M., R. Rogers, H. S. Shauri, M. Rieckmann, and J. C. Habel. 2018. Smallholder perceptions and communication gaps shape East African riparian ecosystems. Biodiversity and Conservation 27: 3745-3757.

Ostrom, E. 2007. A diagnostic approach for going beyond panaceas. Proceedings of the National Academy of Sciences of the United States of America 104(39):15181-7.

Ostrom, E. 2009. A general framework for analyzing sustainability of social-ecological systems. Science (New York, N.Y.) 325(5939): 419-22.

Paloniemi, R., and A. Vainio. 2011. Legitimacy and empowerment: combining two conceptual approaches for explaining forest owners , willingness to cooperate in nature conservation. Journal of Integrative Environmental Sciences 8(2):123-138.

Partelow, S. 2018. A review of the social-ecological systems framework: applications, methods, modifications, and challenges. Ecology and Society 23((4):36).

Partelow, S., M. Fujitani, V. Soundararajan, and A. Schlüter. 2019. Transforming the social-ecological systems framework into a knowledge exchange and deliberation tool for comanagement. Ecology and Society 24(1).

Partelow, S., A. Schlüter, D. Armitage, M. Bavinck, K. Carlisle, R. L. Gruby, A.-K. Hornidge, M. Le Tissier, J. B. Pittman, A. M. Song, L. P. Sousa, N. Văidianu, and K. Van Assche. 2020. Environmental governance theories: a review and application to coastal. Ecology \& Society 25(4). 
Pini, B., J. Previte, and F. H. McKenzie. 2007. Stakeholders, natural resource management and Australian rural local governments: A Q-methodological study. Local Government Studies 33(3):427-449.

Pokorny, J. J., A. Norman, A. P. Zanesco, S. Bauer-Wu, B. K. Sahdra, and C. D. Saron. 2018. Network analysis for the visualization and analysis of qualitative data. Psychological Methods 23(1):169-183.

Pulver, S., N. Ulibarri, K. L. Sobocinski, S. M. Alexander, M. L. Johnson, and P. F. Mccord. 2018. Frontiers in socio-environmental research: components, connections, scale, and context. Ecology and Society 23(3).

Pyhälä, A., Á. Fernández-Llamazares, H. Lehvävirta, A. Byg, I. RuizMallén, M. Salpeteur, and T. F. Thornton. 2016. Global environmental change: Local perceptions, understandings, and explanations. Ecology and Society 21(3).

R Core Team. 2018. R: A language and environment for statistical computing. R Foundation for Statistical Computing, Vienna.

Raymond, C. M., B. A. Bryan, D. H. MacDonald, A. Cast, S. Strathearn, A. Grandgirard, and T. Kalivas. 2009. Mapping community values for natural capital and ecosystem services. Ecological Economics 68(5):1301-1315.

Reddy, S. M. W., J. Montambault, Y. J. Masuda, E. Keenan, W. Butler, J. R. B. Fisher, S. T. Asah, and A. Gneezy. 2017. Advancing Conservation by Understanding and Influencing Human Behavior. Conservation Letters 10(March):248-256.

Rivera, V. S., P. M. Cordero, D. C. Rojas, and B. O'Riordan. 2017. Institutions and collective action in a Costa Rican small-scale fisheries cooperative: the case of CoopeTárcoles R.L. Maritime Studies 16(1):22.

Rohe, J. R., S. Aswani, A. Schlüter, and S. C. A. Ferse. 2017. Multiple Drivers of Local ( Non- ) Compliance in Community-Based Marine Resource Management : Case Studies from the South Pacific 4(May).

Sabau, G. 2017. Costa Rica: A champion of the Small-Scale Fisheries Guidelines. Page in S. Jentoft, R. Chuenpagdee, M. J. BarragánPaladines, and N. Franz, editors. The Small-Scale Fisheries Guidelines: Global Implementation. Springer.

Saunders, C. D., A. T. Brook, and O. E. Myers. 2006. Using psychology to save biodiversity and human well-being. Conservation Biology 20:702-705.

SESMAD. 2014. Social-Ecological Systems Meta-Analysis Database. http://sesmad.dartmouth.edu/.
Simpson, S., G. Brown, A. Peterson, and R. Johnstone. 2016. Stakeholder perspectives for coastal ecosystem services and influences on value integration in policy. Ocean \& Coastal Management 126:9-21.

Spranz, R., A. Schlüter, and B. Vollan. 2018. Morals, money or the master: The adoption of eco-friendly reusable bags. Marine Policy(January):0-1.

Steg, L., A. E. van den Berg, and J. I. De Groot, editors. 2012. Environmental psychology: An introduction. John Wiley \& Sons.

Steg, L., and C. Vlek. 2009. Encouraging pro-environmental behaviour: An integrative review and research agenda. Journal of Environmental Psychology 29(3):309-317.

Stemler, S. 2001. An Overview of Content Analysis. Practical Assessment, Research \& Evaluation 7(17).

Stern, P. C. 2000. Psychology and the science of human-environment interactions. American Psychologist 55:523-530.

Sullivan, A., A. M. York, L. An, S. T. Yabiku, and S. J. Hall. 2017. How does perception at multiple levels influence collective action in the commons? The case of Mikania micrantha in Chitwan, Nepal. Forest Policy and Economics 80:1-10.

Turner, R. A., J. Forster, C. Fitzsimmons, D. Gill, R. Mahon, A. Peterson, and S. Stead. 2018. Social fit of coral reef governance varies among individuals. Conservation Letters 11(3):1-9.

Vlek, C., and L. Steg. 2007. Human Behavior and Environmental Sustainability: Problems, Driving Forces, and Research Topics. Journal of Social Issues 63(1):1-20.

Wagner, C. R. H. 2019. Strengthening The Institution-Behaviour Link In the SES Framework To Faciliate Analysis Of Environmental Public Goods Dilemmas. Complexity, Governance \& Networks 5(1):5-23.

Ward, B. M., E. D. Doney, K. Vodden, and A. J. Bath. 2018. The importance of beliefs in predicting support for a South Coast National Marine Conservation Area in Newfoundland and Labrador, Canada. Ocean and Coastal Management 162(December 2016):612.

Yoeli, E., D. V Budescu, A. R. Carrico, A. Magali, J. R. Deshazo, P. J. Ferraro, H. A. Forster, R. P. Larrick, M. Lubell, E. M. Markowitz, B. Tonn, M. P. Vandenbergh, and E. U. Weber. 2017. Behavioral science tools to strengthen energy \& environmental policy. Behavioral Science \& Policy 3(1):69-79.

Publisher's Note Springer Nature remains neutral with regard to jurisdictional claims in published maps and institutional affiliations. 